\title{
Review
}

\section{CaMKII in cerebral ischemia}

\author{
Steven J COULTRAP ${ }^{1}$, Rebekah S VEST ${ }^{1}$, Nicole M ASHPOLE ${ }^{2}$, Andy HUDMON², 3,, $\mathrm{K} \mathrm{Ulrich} \mathrm{BAYER}^{1, *}$ \\ ${ }^{1}$ Department of Pharmacology, University of Colorado Denver-School of Medicine, Aurora, C0 80045, USA; ${ }^{2}$ Stark Neuroscience \\ Research Institute, ${ }^{3}$ Department of Biochemistry and Molecular Biology, Indiana University School of Medicine, Indianapolis, IN 46202, \\ USA
}

Ischemic insults on neurons trigger excessive, pathological glutamate release that causes $\mathrm{Ca}^{2+}$ overload resulting in neuronal cell death (excitotoxicity). The $\mathrm{Ca}^{2+} /$ calmodulin (CaM)-dependent protein kinase II (CaMKII) is a major mediator of physiological excitatory glutamate signals underlying neuronal plasticity and learning. Glutamate stimuli trigger autophosphorylation of CaMKII at T286, a process that makes the kinase "autonomous" (partially active independent from $\mathrm{Ca}^{2+}$ stimulation) and that is required for forms of synaptic plasticity. Recent studies suggested autonomous CaMKII activity also as potential drug target for post-insult neuroprotection, both after glutamate insults in neuronal cultures and after focal cerebral ischemia in vivo. However, CaMKII and other members of the CaM kinase family have been implicated in regulation of both neuronal death and survival. Here, we discuss past findings and possible mechanisms of CaM kinase functions in excitotoxicity and cerebral ischemia, with a focus on CaMKII and its regulation.

Keywords: brain ischemia; excitotoxicity; glutamate; CaMKII; CaM kinases; stroke

Acta Pharmacologica Sinica (2011) 32: 861-872; doi: 10.1038/aps.2011.68; published online 20 Jun 2011

\section{Introduction}

Global cerebral ischemia is caused by a general loss of oxygen supply to the brain (during drowning, suffocation, or cardiac arrest). While the increased availability of automated external defibrillators has dramatically increased the survival rate after cardiac arrest, survivors may suffer from neuronal damage caused by the oxygen deficit in the brain. Despite increased demand for a neuroprotective treatment of global cerebral ischemia, no effective therapy has been developed to date. Focal cerebral ischemia (stroke) also involves decreased oxygen supply to parts of the brain. However, focal cerebral ischemia is caused by regional lack of blood supply after clotting or hemorrhage of blood vessels in the brain. The focal core area of the stroke is generally considered to be beyond rescue, however, neurons in the surrounding penumbra (where secondary cell loss occurs) are potential targets for therapeutic intervention $^{[1]}$ (Figure 1). Currently, the only available FDA approved pharmacological treatment is haemolytic therapy with tissue plasminogen activator (tPA). However, $\mathrm{tPA}$ is contra-indicated in hemorrhagic stroke, and by the time most

\footnotetext{
* To whom correspondence should be addressed.

E-mail ulli.bayer@ucdenver.edu (K Ulrich BAYER); ahudmon@iupui.edu (Andy HUDMON)

Received 2011-03-03 Accepted 2011-04-22
}

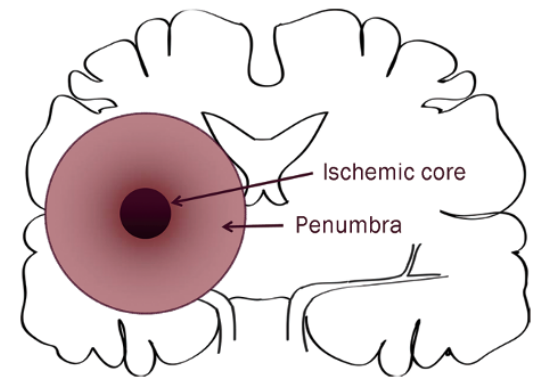

Figure 1. Ischemic core and penumbra after stroke. While neurons in the ischemic core are considered beyond rescue, neurons in the penumbra are potential targets for therapeutic intervention.

patients receive diagnostic evaluation, tPA is no longer effective (and may even do more harm than good) $)^{[2-4]}$. Thus, less than $2 \%$ of stroke patients actually receive $\mathrm{tPA}^{[5]}$, leaving a significant void in therapies that are more universally applicable for stroke treatment. Two independent studies recently implicated CaMKII as a promising drug target for post-insult neuroprotection $^{[6,7]}$. Here, we discuss the CaM kinase family and its possible involvement in the regulation of neuronal cell death, with a focus on CaMKII and its regulation. 
Glutamate excitotoxicity causes neuronal cell death after cerebral ischemia

Glutamate is the major excitatory neurotransmitter in the mammalian brain. However, excessive glutamate also leads to neuronal cell death via "glutamate excitotoxicity", a process that involves $\mathrm{Ca}^{2+}$ overload ${ }^{[8]}$ and that was first demonstrated in retinal neurons ${ }^{[0]}$, and subsequently in the brain ${ }^{[10,11]}$. Ischemic conditions trigger anoxic depolarization of neurons, which in turn triggers massive release of glutamate $e^{[1,12,13]}$. It is thought that the excitotoxic effect of such glutamate overstimulation causes much of the neuronal cell death seen following cerebral ischemia ${ }^{[13-16]}$. Additionally, excitotoxic glutamate signaling is thought to contribute to neuronal cell death after traumatic brain injury and in neurodegenerative diseases ${ }^{[16-18]}$. Excitotoxicity can cause neuronal death with apoptotic or necrotic appearance ${ }^{[19,20]}$, but both may involve similar signaling pathways despite a different morphological end state ${ }^{[1,21,22]}$. Overstimulation of most glutamate receptors can cause neuronal cell death, but the $\mathrm{Ca}^{2+}$ conducting NMDA-type glutamate receptors appear to be the most sensitive "death receptors" ${ }^{[23-26]}$ : Even relatively brief ( $\left.\sim \mathrm{min}\right)$ application of glutamate or NMDA to cultured neurons can trigger signaling events that cause significant cell death within $24 \mathrm{~h}$. Consequently, extensive efforts were made to develop NMDA-receptor inhibitors into stroke therapies, unfortunately without success ${ }^{[27,28]}$. Alternative strategies include targeting signaling molecules downstream of the NMDA-receptor, such as CaMKII, which has been shown to mediate key effects of physiological NMDA-receptor stimulation in neuronal plasticity and learning and memory ${ }^{[29-31]}$.

\section{CaMKII and the CaM kinase family}

CaM kinases (Figure 2) are a large family of Ser/Thr protein kinases that include kinases with broad substrate spectrum (ie multifunctional kinases such as CaMKI, CaMKII, and CaMKIV) and with high substrate selectivity [ie dedicated kinases such as myosin light chain kinases (MLCKs) and phosphorylase kinase $(\mathrm{PhK})]$. As the name implies, CaM kinases are gen-

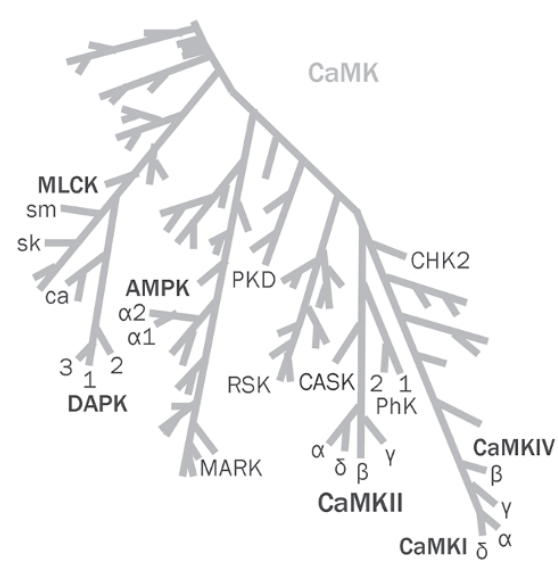

Figure 2. The CaM kinase family tree ${ }^{[33]}$, with a limited number of example CaM kinases marked. erally activated by binding of $\mathrm{Ca}^{2+} / \mathrm{CaM}$ to their regulatory region. However, several CaM kinases (including DAPK3 and AMPKs) lack a CaM-binding regulatory region, but are included in the CaM kinase family based on high homology of their core kinase domain. Regulation by $\mathrm{Ca}^{2+} / \mathrm{CaM}$ does not automatically classify a kinase in the CaM kinase family. For instance, CaMKIII (now termed eEF2 kinase), which is also activated by $\mathrm{Ca}^{2+} / \mathrm{CaM}$, is not closely related to the other CaM kinases $^{[32]}$ and is instead grouped with the family of atypical protein kinases ${ }^{[33]}$. Like many other kinases (including PKA, $\mathrm{PKB} / \mathrm{Akt}$, and PKC), several CaM kinase family members require phosphorylation within the activation loop of their core kinase domain for full activity (including CaMKI T177, CaMKIV T196, and AMPKs T172). Interestingly, an upstream kinase that phosphorylates the activation loop of CaMKI, CaMKIV, and AMPK (as well as PKB/Akt, which is not a CaM kinase) is CaMKK, which is itself a $\mathrm{Ca}^{2+} / \mathrm{CaM}$-stimulated kinase $^{[34]}$. However, other CaM kinases (including CaMKII and DAPKs) do not even have a phosphorylatable residue at the homologous activation loop position, even though their activity can be regulated by other phosphorylation events outside of their core kinase domains (such as T286 of CaMKII, which makes the kinase partially $\mathrm{Ca}^{2+} / \mathrm{CaM}$-independent ${ }^{[35-38]}$, and 5735 of DAPK1, which further enhances $\mathrm{Ca}^{2+} / \mathrm{CaM}$ stimulated activity ${ }^{[39]}$ ).

Functionally, DAPKs (death associated protein kinases) are associated with regulation of cell death ${ }^{[40]}$, MLCKs (myosin light chain kinases) regulate smooth muscle contraction ${ }^{[41]}$, and AMPKs (AMP activated kinases) are regulators of energy metabolism ${ }^{[42]}$. CaMKI, CaMKII, and CaMKIV have been implicated in various neuronal functions, including plasticity ${ }^{[30,31,43]}$. CaMKII comprises a family of closely related kinases, with four isoforms ( $\alpha, \beta, \gamma$, and $\delta$ ) encoded by different genes, and alternative splicing gives rise to additional diversity ${ }^{[3]}$. At least one CaMKII isoform was found to be expressed in every cell type examined, with CaMKIIY and CaMKII $\delta$ being the most ubiquitous isoforms ${ }^{[44,45]}$. CaMKIIa is almost exclusively expressed in brain, where it is also extremely abundant, making up more than $1 \%$ of total protein in some brain regions, such as the hippocampus ${ }^{[46]}$. Notably, the hippocampus, specifically its CA1 region, is also the brain area that is most sensitive to damage following global cerebral ischemia ${ }^{[47]}$. The hippocampus is important in memory formation, and the CaMKIIa knockout mice were the first knockout mice described to show impaired neuronal plasticity and learning $^{[48,49]}$.

\section{CaMKII structure and regulation}

The relationship between CaMKII structure and regulation has been reviewed previously in detail ${ }^{[31]}$. However, there have since been several significant advances, especially regarding CaMKII structure ${ }^{[50-53]}$ (Figure 3). CaMKII forms 12meric holoenzymes, with the C-terminal association domains forming a central hub and the $\mathrm{N}$-terminal kinase domains radiating outwards like spokes or petals (Figure 3A). Between the core kinase domain and the association domain, the CaMKII 
A

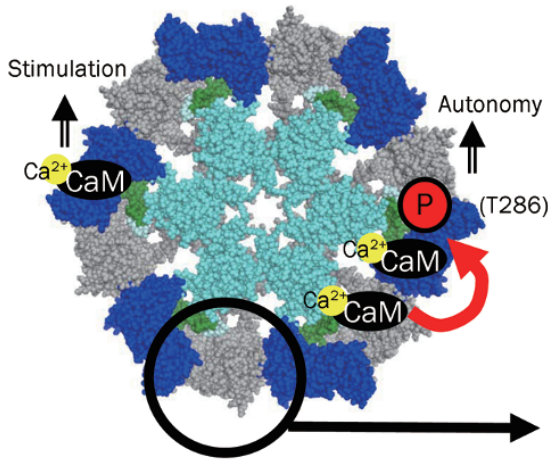

B

Kinase domain (spacefill)

+regulatory $\alpha$-helix (ribbon)

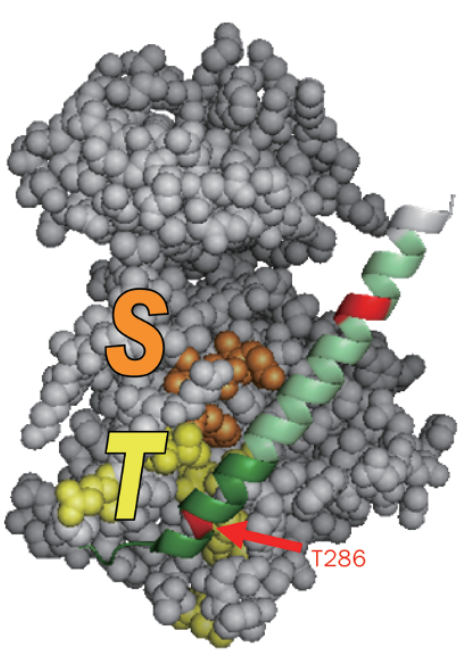

Figure 3. CaMKII structure $\mathrm{e}^{[50,51]}$ and regulation. (A) CaMKII forms multimeric holoenzymes via C-terminal association domains (acqua). Each kinase domain (grey, dark blue) is stimulated separately by $\mathrm{Ca}^{2+}$ / CaM binding, but intersubunit autophosphorylation at T286 generates autonomous activity that persists even after dissociation of $\mathrm{Ca}^{2+} / \mathrm{CaM}$. (B) In the basal state, the regulatory $\alpha$-helix (ribbon) interacts with the T-site (yellow) and prevents access to the substrate binding S-site (orange). Autophosphorylation sites (red) generate autonomous activity (T286) or prevent CaM binding (T305/306) and affect targeting. (C) The sequence of the regulatory $\alpha$-helix. The regions contributing to CaM-binding and to auto-inhibition are marked.

subunits contain a $\mathrm{Ca}^{2+} / \mathrm{CaM}$-binding autoregulatory region followed by a variable region that is subject to extensive alternative splicing. The largest described splice variant is CaMKII $\beta \mathrm{M}(72 \mathrm{kDa})^{[54]}$; the dominant isoforms in brain are a $(50 \mathrm{kDa})$ and $\beta(60 \mathrm{kDa})^{[5,56]}$. Holoenzymes can be homomeric or heteromeric (ie formed by subunits of the same or different isoforms $)^{[54,56-60]}$, with a molecular weight of $\sim 600-750 \mathrm{kDa}$ and a diameter of $\sim 20 \mathrm{~nm}^{[38,50-52,61,62]}$.

The a-helical autoregulatory region is responsible for holding CaMKII in an inactive state under basal conditions (Figure 3B). Its N-terminal part surrounding T286 interacts with the core kinase domain at a region termed the T286-binding site (T-site $)^{[51,63,64]}$. When the autoregulatory region is bound to the T-site, access to the adjacent substrate binding S-site is blocked, thus preventing CaMKII activity (Figure 3B). Each kinase subunit within a holoenzyme is activated separately by direct binding of $\mathrm{Ca}^{2+} / \mathrm{CaM}$ to the autoregulatory region ("stimulated activity"). This $\mathrm{Ca}^{2+} / \mathrm{CaM}$-binding displaces the autoregulatory region from the T-site, allowing the kinase to make other protein-protein interactions via the T-site (see below). Importantly, displacement of the autoregulatory region also allows access to the S-site, thereby activating the kinase. Additionally, releasing T286 from the T-site makes T286 accessible for auto-phosphorylation by neighboring subunits within the holoenzyme, provided these neighboring subunits are also activated with an exposed S-site ${ }^{[6,66]}$. This autophosphorylation of T286 prevents complete re-association of the autoregulatory region with the T- and S-sites, leaving CaMKII partially active even after dissociation of $\mathrm{Ca}^{2+} / \mathrm{CaM}$ ("autonomous activity") $)^{[35-37,67]}$. This autonomous activity has been described as a molecular memory mechanism and is indeed important for synaptic plasticity and learning ${ }^{[67,68]}$. More recently, autonomous CaMKII activity has also been identified as a drug target for post-insult neuroprotection ${ }^{[6,7]}$.

An additional regulatory auto-phosphorylation at T305/306 can occur as an intra-subunit reaction and prevents subsequent $\mathrm{Ca}^{2+} / \mathrm{CaM}$ binding ${ }^{[69-72]}$ (Figure 3B). Vice versa, $\mathrm{Ca}^{2+} /$ $\mathrm{CaM}$ binding prevents this inhibitory auto-phosphorylation. Thus, efficient T305/306 auto-phosphorylation occurs only after generation of autonomous activity by T286 autophosphorylation and subsequent $\mathrm{Ca}^{2+} / \mathrm{CaM}$ dissociation. Such a triple-phosphorylated CaMKII would be locked in a partially active state that cannot be further stimulated ${ }^{[67]}$, but it would be completely inactivated only after selective T286 dephosphorylation.

\section{Glutamate-induced translocation of CaMKII}

$\mathrm{Ca}^{2+}$-influx through NMDA-type glutamate receptors stimulates CaMKII activity and T286 auto-phosphorylation. Both are required for induction of long-term potentiation of synaptic strength ${ }^{[68,73,74]}$, a form of synaptic plasticity underlying learning and memory ${ }^{[29,30,75]}$. Additionally, glutamateinduced $\mathrm{Ca}^{2+}$-influx causes two forms of CaMKII translocation: (i) to post-synaptic sites ${ }^{[64,76-78]}$, and (ii) to extra-synaptic clusters $^{[79-82]}$. Synaptic translocation occurs after physiological glutamate stimuli and is involved in synaptic plasticity ${ }^{[83,84]}$. Several synaptic proteins have been described as binding partners for CaMKII, but the NMDA receptor subunit GluN2B (formerly known as NR2B) appears to be most important for CaMKII translocation to the synaps $\mathrm{e}^{[64,78,85-89]}$. Extra-synaptic clustering has been described after pathological glutamate stimuli and ischemic conditions ${ }^{[79-82]}$, and is likely mediated by 
self-association of multiple CaMKII holoenzymes into large insoluble complexes ${ }^{[79,90,91]}$, a process here termed aggregation. Both types of translocation require protein-interactions via the CaMKII T-site, specifically T-site binding to the GluN2B region around $\mathrm{S} 1303^{[64,85,92]}$ or the region around T286 of a CaMKII subunit within another holoenzyme ${ }^{[82,90,91]}$. Accordingly, both interactions require $\mathrm{Ca}^{2+} / \mathrm{CaM}$-binding, in order to make the $\mathrm{T}$-site accessible. Both interactions are also enhanced by nucleotide. However, holoenzyme aggregation in vitro requires mimicking ischemic conditions, ie low ATP/ADP ratio and low $\mathrm{pH}$. High ATP concentrations favor T286 auto-phosphorylation, which enhances CaMKII binding to GluN2B ${ }^{[6,85]}$, but inhibits CaMKII aggregation (as it inhibits interaction of T286 with the T-site) ${ }^{[91]}$. The molecular basis for requirement of a pH below 6.8 for CaMKII aggregation is unclear, but may involve protonation of His282, which is located at the hinge of the auto-regulatory a-helix (Figure 3B). CaMKII aggregation causes a reduction in the degree of activity that can be stimulated by $\mathrm{Ca}^{2+} / \mathrm{CaM}^{[79]}$, an effect also observed in brain after ischemia ${ }^{[93-95]}$. For this reason, it has been speculated that CaMKII aggregation may be a neuroprotective mechanism, as it would limit aberrant CaMKII activity during disregulated, pathological $\mathrm{Ca}^{2+}$ signaling ${ }^{[79]}$. However, the potential neuroprotective functions of CaMKII aggregation have yet to be determined.

\section{Inhibitors of CaMKII}

The traditional small molecule CaMKII inhibitors KN62 and $\mathrm{KN} 93^{[96,97]}$ have proved to be very useful tools for studying CaMKII functions in cells, as they are membrane penetrating and their selectivity for CaMKII is relatively good ${ }^{[96-98]}$. However, the KN inhibitors cannot distinguish between CaMKII and CaMKIV ${ }^{[99]}$. Through an unusual affect on the scaffolding protein AKAP79/150 $0^{[100]}, \mathrm{KN}$ inhibitors can also inhibit PKC action at the synapse ${ }^{[101]}$. Maybe more importantly, KN inhibitors additionally affect voltage gated $\mathrm{Ca}^{2+}$ and $\mathrm{K}^{+}$channels ${ }^{[102,103]}$. Another limitation is that both KN62 and KN93 are competitive with CaM and inhibit only stimulated but not autonomous CaMKII activity ${ }^{[6,96,97]}$. Peptide inhibitors derived from the CaMKII autoregulatory region, such as AC3-I or $\mathrm{AIP}^{[7,104,105]}$, are generally thought to be more selective than the $\mathrm{KN}$ compounds. However, they can also inhibit other kinases, including PKC, MLCK, and PKD ${ }^{[106-108]}$. Additionally, some studies indicated a relatively low potency $\left(\mathrm{IC}_{50}\right.$ of $\sim 3$ $\mu \mathrm{mol} / \mathrm{L})^{[109,110]}$.

More recently, an alternative was provided by CN21, a potent and selective CaMKII inhibitor ${ }^{[111]}$. CN21 is a 21 mer peptide derived from the natural CaMKII inhibitory protein CaM-KIIN ${ }^{[112]}$. Peptides and even proteins can be made cell penetrating by fusion with sequence motifs such as ant/ penetratin or tat ${ }^{[113-115]}$. In initial attempts to make $\mathrm{CN}$ peptides cell penetrating, ant fusion was used ${ }^{[116,117]}$. However, it was subsequently shown that the ant/penetratin sequence directly binds $\mathrm{CaM}$, an effect further enhanced by fusion with $\mathrm{CN} 21^{[74]}$. Thus, while fusion of $\mathrm{CN}$ to ant added an additional CaMKII-inhibitory mechanism, selectivity for CaMKII was compromised. However, alternative fusion of $\mathrm{CN} 21$ to tat still allowed cell-penetration without the caveat of binding $\mathrm{CaM}^{[74]}$. The resulting tatCN21 is a potent $\left(\mathrm{IC}_{50}\right.$ of $\left.\sim 50 \mathrm{nmol} / \mathrm{L}\right)$, selective, and cell penetrating peptide inhibitor of both stimulated and autonomous CaMKII activity ${ }^{[6,74,111]}$. Consistent with previous reports that tat fusion peptides can cross the blood brain barrier ${ }^{[26,118]}$, tatCN21 inhibited CaMKII functions in brain even after systemic application ${ }^{[6,74]}$.

\section{CaMKII autonomy as a drug target for post-insult neuro- protection}

Inhibiting stimulated and autonomous CaMKII activity with tatCN21 attenuated neuronal cell death induced by glutamate insult in primary cultures as well as in a mouse model of stroke (middle cerebral arterial occlusion; MCAO), even when administered significantly after the insult ${ }^{[6]}$. The longest postinsult time periods tested in this study were $6 \mathrm{~h}$ in hippocampal cultures, $1 \mathrm{~h}$ in cortical cultures, and $1 \mathrm{~h}$ in vivo[ ${ }^{[6]}$. A recent study independently confirmed post-insult neuroprotection by CaMKII inhibition, using both tatCN21 and tatAIP ${ }^{[7]}$. This study found significant neuroprotection in cortical cultures also when tatCN21 was administered $2 \mathrm{~h}$ after the insult $\mathrm{t}^{[7]}$. By contrast, the traditional CaMKII inhibitor KN93 was neuroprotective only when administered during but not after the insult in both studies ${ }^{[6,7]}$. During an insult, tatCN21, tatAIP, and KN93 can inhibit CaMKII activation and/or generation of autonomous activity. However, after the insult, tatCN21 and tatAIP but not KN93 can inhibit autonomous CaMKII activity that has already been generated. Thus, these findings indicated that autonomous CaMKII activity is the relevant drug target for post-insult neuroprotection by tatCN21. Indeed, overexpression of CaMKII wild-type or the constitutively autonomous T286D mutant (which mimics T286 phosphorylation) increased glutamate-induced neuronal death significantly more than overexpression of the autonomy-incompetent T286A mutant ${ }^{[6]}$. Consistent with these recent results ${ }^{[6,7]}$, neuroprotection by CaMKII inhibition had been described previously, although only for inhibition during or prior to excitotoxic insults ${ }^{[119-123]}$. Protection was seen in cortical cultures ${ }^{[6,7,119,121]}$, hippocampal cultures $^{[6,123]}$ and retinal cells ${ }^{[120,122]}$. However, other studies indicated an opposite effect, ie that abolishing CaMKII activity can promote neuronal cell death ${ }^{[124-128]}$. Some of these results may be explained by different death-inducing stimuli and different culture systems, as cerebellar granule cells and spiral ganglion cells depend on depolarization-induced $\mathrm{Ca}^{2+}$ signals for survival ${ }^{[126-128]}$. Additionally, different results using the inhibitor KN93 may depend on the balance between deathand survival-promoting signals mediated by CaMKII and CaMKIV, respectively ${ }^{[125]}$. Notably, however, genetic knockout of CaMKIIa resulted in increased infarct size in a mouse model of stroke ${ }^{[124]}$, the opposite effect from the observation after acute CaMKII inhibition with tatCN21 ${ }^{[6]}$. This difference could be explained by developmental effects caused by the absence of CaMKIIa. Indeed, the CaMKIIa knock-out mice are epileptic ${ }^{[129]}$, and hyper-excitability may contribute to higher susceptibility to ischemic insults. Additionally, inhibition of 
CaMKII and complete removal of CaMKIIa protein may have profoundly different effects on glutamate-induced neuronal death. Thus, it will be interesting to compare CaMKII knock down by RNAi with CaMKII inhibition in neuronal cultures and to compare CaMKIIa knock-out mice with existing knockin mice that carry the inactive CaMKIIa K42R mutation ${ }^{[130]}$. However, a recent study indicated that long-term (8-24 h) inhibition of CaMKII activity (without loss of CaMKII protein) is sufficient to increase vulnerability to subsequent excitotoxic insults $^{[7]}$, even though acute CaMKII inhibition during or after the insults reduced neuronal cell death (Table 1$)^{[6,7]}$.

Table 1. Post-insult neuroprotection by CaMKII inhibitors ${ }^{[6,7]}$. Tested were glutamate insults in hippocampal and/or cortical cultures, and a MCAO stroke model in mouse. (Stim, stimulated; Aut, autonomous).

\begin{tabular}{|c|c|c|c|c|c|}
\hline \multirow{2}{*}{ Inhibitor } & \multicolumn{2}{|c|}{$\begin{array}{c}\text { CaMKII activity } \\
\text { blocked }\end{array}$} & \multicolumn{3}{|c|}{$\begin{array}{c}\text { Neuroprotection } \\
\text { when applied }\end{array}$} \\
\hline & Stim & Aut & $\begin{array}{l}\text { During } \\
\text { insult }\end{array}$ & $\begin{array}{l}\text { After } \\
\text { insult }\end{array}$ & $\begin{array}{l}\text { After } \\
\text { stroke }\end{array}$ \\
\hline KN93 & $x$ & - & $x$ & - & $?$ \\
\hline tatCN21 & $x$ & $x$ & $x$ & $x$ & $x$ \\
\hline tatAIP & $x$ & $x$ & $x$ & $x$ & ? \\
\hline
\end{tabular}

\section{Other CaM kinases in neuronal death and survival}

CaMKII is not the only CaM kinase family member implicated in the regulation of neuronal survival and cell death. For example, CaMKIV activity has been described to be neuroprotective in multiple systems, likely by its phosphorylation and activation of the transcription factor CREB ${ }^{[127,131-133]}$. CaMKI may have a similar effect, as it can activate Mek/Erk, which, in turn, also activates $\mathrm{CREB}^{[134]}$. CaMKK activity is also neuroprotective, as its inhibition by STO-609 ${ }^{[135]}$ increases neuronal cell death ${ }^{[6]}$. CaMKK is an upstream activator of at least two survival kinases, CaMKIV (see above) and Akt/ PKB (which is not a member of the CaM kinase family) ${ }^{[136]}$. However, CaMKK is also an upstream activator of AMPK, a non-CaM-binding CaM kinase family member that has been implicated in promoting stroke-related neuronal death ${ }^{[137,138]}$. Interestingly, acute treatment with the AMPK activator metformin during stroke insults increases neuronal death, while previous treatment with metformin before the insult reduces cell death ${ }^{[139]}$. This is similar to the phenomenon of ischemic preconditioning, in which previous mild insults can partially protect from the effect of subsequent stronger insults ${ }^{[140-143]}$, indicating that AMPK may be part of a mechanism for this ischemic preconditioning. Thus, AMPK is also a possible target for stroke treatment, however, the effect of therapeutically relevant post-insult AMPK inhibition has not yet been tested $^{[144]}$.

Death-associated protein kinases (DAPKs) are another branch of the CaM kinases family associated with the regulation of cell death and survival ${ }^{[40]}$. DAPK1 has specifically been implicated in mediating excitotoxicity and stroke related death of neurons ${ }^{[145]}$. Interestingly, this required an interaction between DAPK1 and the NMDA-receptor subunit GluN2B ${ }^{[145]}$ at the same site that also interacts with $\mathrm{CaMKII}^{[64,92]}$. This raises the possibility that some of the neuroprotective treatments designed to target DAPK1 or CaMKII may act in part through effects on the other kinase; in fact, targeting both kinases with the same compound may be desirable for maximal therapeutic effect. However, molecular manipulations indicated that targeting each kinase separately is also neuroprotective independent from effects on the other kinase ${ }^{[6,145]}$. Interestingly, manipulations that dissociate the scaffolding protein PSD95 from GluN2B also protect neurons from excitotoxic and stroke induced death ${ }^{[26,146]}$. It has been proposed that this neuroprotection is due to the resulting dissociation of neuronal nitric oxide synthase (nNOS) from the NMDAreceptor $^{[26,146]}$. It will be interesting to test if this manipulation additionally indirectly affects GluN2B interaction with CaMKII and/or DAPK1.

\section{What are the downstream targets for CaMKII after exci- totoxic insults?}

The mechanisms by which inhibition of autonomous CaMKII activity may mediate post-insult neuroprotection are currently unclear. Possible pathways by which CaMKII may participate in the regulation of neuronal death and survival are described below and summarized in Figure 4. Potentially death promoting effects of CaMKII activity include increase of AMPAreceptor single channel conductance by phosphorylating its GluR1 subunit at $S 831^{[147,148]}$. This effect is especially pronounced for GluR1-homomeric AMPA-receptors ${ }^{[149]}$, which are (in contrast to GluR2 containing channels) $\mathrm{Ca}^{2+}$-conducting ${ }^{[150,}$ ${ }^{151]}$, and could thus further promote death-inducing $\mathrm{Ca}^{2+}$ overload. Indeed, such $\mathrm{Ca}^{2+}$-conducting AMPA-receptors have been implicated in ischemic injury ${ }^{[152]}$. CaMKII could also further increase the $\mathrm{Ca}^{2+}$ overload by facilitating or potentiating L-type voltage dependent $\mathrm{Ca}^{2+}$ channels (VDCCs) via their a or $\beta$ subunits ${ }^{[153,154]}$. Additionally, CaMKII can directly interact with connexin hemichannels ${ }^{[155]}$, which are important in neuronal homeostasis and for neuron-glia communication and have been implicated in glutamate-induced cell death ${ }^{[156-158]}$. CaMKII activity may also contribute to neuronal cell death through phosphorylation of acid-sensing ion channels, which enhances the ischemia-induced activation of the ion channel ${ }^{[123]}$. Recently, CaMKII activity was also shown to be required for ischemia-induced shuttling of cytoplasmic polyadenylation element binding 4 (CPEB4) into the nucleus ${ }^{[159]}$. $\mathrm{CPEBs}$ regulate cytoplasmic polyadenylation and translation in neurons ${ }^{[160,161]}$, and some cross-talk between CPEB1 and CaMKII signaling has been described ${ }^{[162,163]}$. CPEB4 knock down induces neuronal death, which can be rescued by reexpression of CPEB4 wild type, but not to the same extent by its nuclear export-incompetent mutant ${ }^{[159]}$. Thus, nuclear retention of CPEB4 by CaMKII activity may contribute to ischemia-induced neuronal death. Another protein that induces neuronal death upon nuclear shuttling is apoptosis inducing 


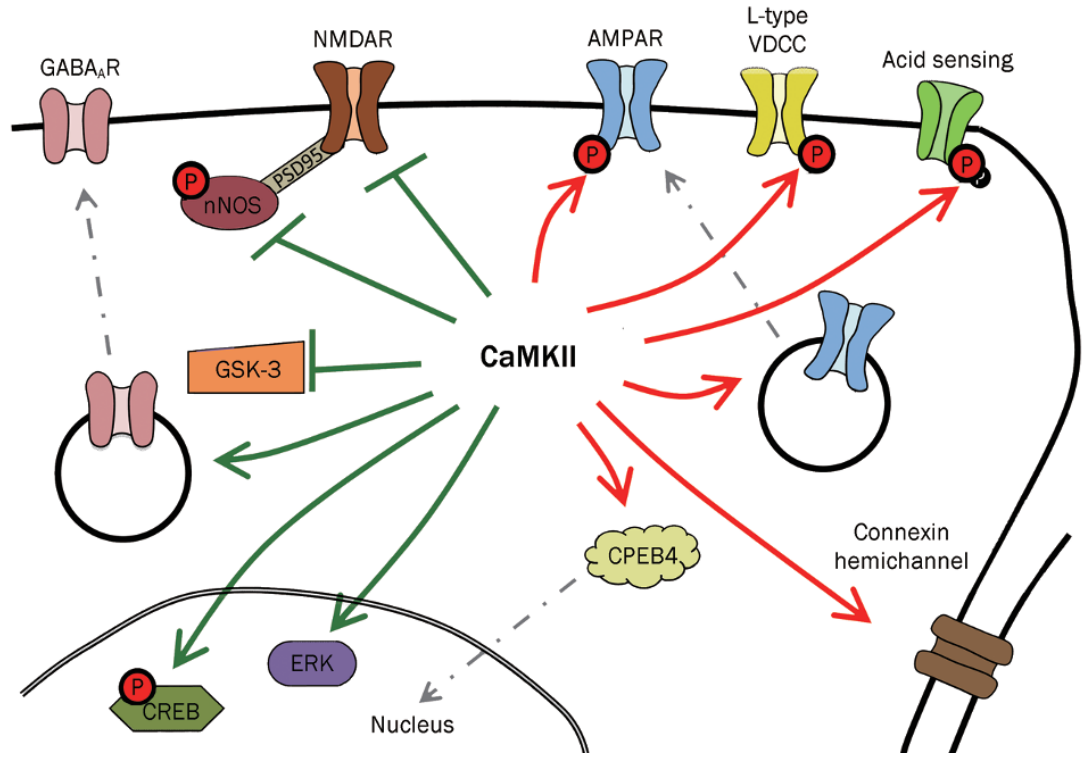

Figure 4. CaMKII downstream targets that may be involved in regulation of neuronal viability. CaMKII signaling may promote excitotoxic cell death (red) or neuronal survival (green). Activation (arrow) or inhibition (bar) of the downstream targets is indicated. Some but not all of these downstream effects are mediated by direct phosphorylation of the target. factor $(\mathrm{AIF})^{[164]}$. However, involvement of CaMKII in nuclear shuttling of AIF has not yet been tested.

On the other hand, several downstream effects of CaMKII activity could instead promote neuronal survival. Maybe most prominently, CaMKII can phosphorylate and inhibit nNOS ${ }^{[165-168]}$, thereby reducing production of nitric oxide, which is neuro-toxic ${ }^{[14,169-172]}$. CaMKII can also regulate several ion channels in a way that may afford neuroprotection from excitotoxic insults: It promotes desensitization NMDA-receptors $^{[173]}$, and it enhances surface expression of the inhibitory $\mathrm{GABA}_{\mathrm{A}}$-receptors ${ }^{[174,175]}$. Additionally, CaMKII can activate pro-survival proteins such as Erk ${ }^{[117,176]}$ and $\mathrm{CREB}^{[177]}$, inhibit death-promoting proteins such GSK-3 ${ }^{[178]}$ and Bad ${ }^{[127]}$. CaMKII can also promote neuronal survival by inhibiting HDAC $5^{[126]}$, a CaMKII substrate that inhibits the pro-survival transcription factor $\mathrm{MEF}^{[179]}$. These possible mechanisms may explain why the effect of CaMKII inhibition on cell survival can depend on the cell type and/or the death-inducing stimulus. Maybe more importantly, it may also explain why prolonged reduction of CaMKII activity increases vulnerability to subsequent excitotoxic insults ${ }^{[7,124]}$. However, there is ample evidence that acute CaMKII inhibition protects hippocampal, cortical, and retinal neurons from glutamate excitotoxicity ${ }^{[6,7,119-123]}$, consistent with the neuroprotection seen in a mouse model of stroke ${ }^{[6]}$.

\section{CaMKII regulation of apoptotic cell death: lessons from non-neuronal systems?}

Apoptosis is a common mechanism of regulated cell death that involves caspase activation, nuclear condensation, and DNA fragmentation ${ }^{[180-183]}$. $\mathrm{Ca}^{2+}$ signaling and CaMKII have been linked to the regulation of apoptosis also in non-neuronal systems. However, as for the neuronal CaMKII targets discussed above, some of these links to apoptosis can promote cell death while others promote survival. CaMKII has been shown to be involved in mediating apoptosis induced by TNFa and
UV irradiation ${ }^{[184]}$ microcystein (phosphatase inhibitor) ${ }^{[185,186]}$, GW7845 (PPARy agonist) ${ }^{[187]}$, ER stress ${ }^{[188]}$, TRAIL ${ }^{[189]}$, and -in cardiac myocytes- by isoproterenol ( $\beta$ adrenergic agonist $)^{[190,191]}$, ouabain $\left(\mathrm{Na}^{+} / \mathrm{K}^{+} \text {-ATPase inhibitor }\right)^{[192]}$, oxidative stress (induced by $\mathrm{H}_{2} \mathrm{O}_{2}$ or angiotensin II) ${ }^{[193-195]}$, and cardiac ischemia ${ }^{[196-198]}$. In these cases, CaMKII inhibition attenuated apoptotic death. However, CaMKII inhibition has also been described to enhance apoptosis, indicating that CaMKII can also suppress apoptosis in other systems ${ }^{[199-204]}$. Anti-apoptotic CaMKII mechanisms included inhibition of caspase $2^{[199]}$, enhancing expression of Bcl-xL ${ }^{[203]}$, and promoting Akt-mediated inhibition of Bad ${ }^{[204]}$. Interestingly, CaMKIImediated activation of Akt has been linked to both pro- ${ }^{[189]}$ and anti-apoptotic ${ }^{[200,201,204]}$ functions.

In the heart, CaMKII contributes to cell death in response to a variety of insults, and CaMKII inhibition consistently promoted cell survival ${ }^{[205]}$ (see above). However, even in the heart, the situation is more complicated: While cytoplasmic CaMKII isoforms were consistently found to promote cell death, nuclear isoforms (ie CaMKII $\left.\delta_{\mathrm{B}}\right)^{[206]}$ may instead promote survival ${ }^{[194,207]}$.

Clearly, the mechanisms by which CaMKII can regulate cell viability are complex and in need of further elucidation. However, the dual role for CaMKII in mediating both cell survival and death may not be that surprising after all, given that its principal activator, $\mathrm{Ca}^{2+}$, is already well established to mediate both $^{[208,209]}$. Even $\mathrm{Ca}^{2+}$ signaling mediated by NMDA receptors can promote not only death but also survival ${ }^{[210,211]}$. Generally, CaMKII appears likely to have pro-survival function in systems and situations in which $\mathrm{Ca}^{2+}$ is required for maintaining cell viability (such as activity-mediated neuronal survival). By contrast, in situations where $\mathrm{Ca}^{2+}$ acts instead as a trigger of death signaling, CaMKII is likely to be involved as a major mediator of cell death (such as in cerebral ischemia and exitotoxicity). 


\section{Concluding remarks and therapeutic potential}

Recent results implicated that autonomous activity of CaMKII, induced by T286 auto-phosphorylation, provides a promising drug target for post-insult neuroprotection after cerebral ischemia and possibly other conditions involving glutamate excitotoxicity ${ }^{[6,7]}$. In the future, therapy development may include identification of selective small-molecule inhibitors of autonomous CaMKII. However, the peptide inhibitor tatCN21 itself also holds promise, as it was effective even after systemic delivery in an animal mode ${ }^{[6,74]}$. The toxicology for tatCN21 is still lacking, but no immediately obvious toxic effects were observed in mice. TatCN21 did interfere with learning in mice, which could be a potential contraindication for chronic treatment in humans ${ }^{[74]}$. However, for acute treatment after stroke, a temporary learning impairment would be more than acceptable, especially since tatCN21 did not interfere with memory storage or retrieval ${ }^{[74]}$, and is thus unlikely to induce retrograde amnesia. Potency of tatCN21 is very reasonable, with an $\mathrm{IC}_{50}$ of $\sim 50 \mathrm{nmol} / \mathrm{L}^{[74]}$, and further improvements of potency may be possible. However, further studies are needed in order to elucidate the downstream mechanisms linking CaMKII to the neuronal cell death that is induced by ischemic conditions. Additionally, the window of therapeutic opportunity (at least $1 \mathrm{~h}$ in a mouse model of stroke ${ }^{[6]}$ ) needs to be evaluated more closely after different types of ischemic insults in vivo. After glutamate insults in culture, hippocampal neurons were significantly protected by tatCN21 application even $6 \mathrm{~h}$ after the insult ${ }^{[6]}$, while protection of cortical neurons was only seen when tatCN21 was applied less than $3 \mathrm{~h}$ after the insult ${ }^{[7]}$. This difference may be caused by the type of glutamate insult $\left(400 \mu \mathrm{mol} / \mathrm{L}\right.$ for $5 \mathrm{~min}^{[6]}$, versus $100 \mu \mathrm{mol} / \mathrm{L}$ for $\left.60 \mathrm{~min}^{[7]}\right)$. However, if the difference is instead inherent to the neuronal cell type, tatCN21 may have an even longer window of therapeutic opportunity after global cerebral ischemia, which particularly affects the hippocampus ${ }^{[4]}$, compared to focal cerebral ischemia (stroke). Additionally, the therapeutic potential in other acute conditions involving glutamate excitotoxicity, such as traumatic brain injury, should be evaluated.

\section{Financial disclosure}

The University of Colorado is currently seeking patent protection for tatCN21, its derivatives, and its uses (including the ones outlined here).

\section{Acknowledgements}

The structural model of the CaMKII holoenzyme was kindly provided by Drs Luke CHAO and John KURIYAN (University of California, Berkeley). Support was provided by NIH training grants T32GM007635 and F31NS061584 (RSV), Ralph W and Grace M Showalter (AH), Indiana State Department of Health, Spinal Cord Brain Injury research grant ISDH/ A70-00-079212 (AH), and NIH R01NS052644 (KUB).

\section{References}

1 Liu S, Levine SR, Winn HR. Targeting ischemic penumbra: part I from pathophysiology to therapeutic strategy. J Exp Stroke Transl
Med 2010; 3: 47-55.

2 Weinberger JM. Evolving therapeutic approaches to treating acute ischemic stroke. J Neurol Sci 2006; 249: 101-9.

3 Kaur J, Zhao Z, Klein GM, Lo EH, Buchan AM. The neurotoxicity of tissue plasminogen activator? J Cereb Blood Flow Metab 2004; 24: 945-63.

4 Wang X, Tsuji K, Lee SR, Ning M, Furie KL, Buchan AM, et al. Mechanisms of hemorrhagic transformation after tissue plasminogen activator reperfusion therapy for ischemic stroke. Stroke 2004; 35: 2726-30.

5 Kleindorfer D, Lindsell CJ, Brass L, Koroshetz W, Broderick JP. National US estimates of recombinant tissue plasminogen activator use: ICD-9 codes substantially underestimate. Stroke 2008; 39: 924-8.

6 Vest RS, O'Leary H, Coultrap SJ, Kindy MS, Bayer KU. Effective post-insult neuroprotection by a novel $\mathrm{Ca}^{2+} /$ calmodulin-dependent protein kinase II (CaMKII) inhibitor. J Biol Chem 2010; 285: 2067582.

7 Ashpole NM, Hudmon A. Excitotoxic neuroprotection and vulnerability with CaMKII inhibition. Mol Cell Neurosci 2011; 46: 720-30.

8 Choi DW. Ionic dependence of glutamate neurotoxicity. J Neurosci 1987; 7 : 369-79.

9 Lucas DR, Newhouse JP. The toxic effect of sodium L-glutamate on the inner layers of the retina. AMA Arch Ophthalmol 1957; 58: 193201.

10 Olney JW. Brain lesions, obesity, and other disturbances in mice treated with monosodium glutamate. Science 1969; 164: 719-21.

11 Olney JW, Sharpe LG. Brain lesions in an infant rhesus monkey treated with monsodium glutamate. Science 1969; 166: 386-8.

12 Hubschmann OR, Kornhauser D. Cortical cellular response in acute subarachnoid hemorrhage. J Neurosurgery 1980; 52: 456-62.

13 Doyle KP, Simon RP, Stenzel-Poore MP. Mechanisms of ischemic brain damage. Neuropharmacology 2008; 55: 310-8.

14 Hara MR, Snyder SH. Cell signaling and neuronal death. Annu Rev Pharmacol Toxicol 2007; 47: 117-41.

15 Aarts MM, Tymianski M. Molecular mechanisms underlying specificity of excitotoxic signaling in neurons. Curr Mol Med 2004; 4: 137-47.

16 Bramlett HM, Dietrich WD. Pathophysiology of cerebral ischemia and brain trauma: similarities and differences. J Cereb Blood Flow Metab 2004; 24: 133-50.

17 Greve MW, Zink BJ. Pathophysiology of traumatic brain injury. Mount Sinai Journal of Medicine: J Translation Personalized Med 2009; 76: 97-104.

18 Mattson MP. Excitotoxic and excitoprotective mechanisms: abundant targets for the prevention and treatment of neurodegenerative disorders. Neuromolecular Med 2003; 3: 65-94.

19 Ankarcrona M, Dypbukt JM, Bonfoco E, Zhivotovsky B, Orrenius S, Lipton SA. Glutamate-induced neuronal death: a succession of necrosis or apoptosis depending on mitochondrial function. Neuron 1995; 15: 961-73.

20 McDonald JW, Behrens MI, Chung C, Bhattacharyya T, Choi DW. Susceptibility to apoptosis is enhanced in immature cortical neurons. Brain Res 1997; 759: 228-232.

21 Yuan J, Lipinski M, Degterev A. Diversity in the mechanisms of neuronal cell death. Neuron 2003; 40: 401-13.

22 Broughton BRS, Reutens DC, Sobey CG. Apoptotic mechanisms after cerebral ischemia. Stroke 2009; 40: e331-9.

23 Choi DW, Koh JY, Peters S. Pharmacology of glutamate neurotoxicity in cortical cell culture: attenuation by NMDA antagonists. J Neurosci 1988; 8: 185-96. 
24 Frandsen A, Drejer J, Schousboe A. Direct evidence that excitotoxicity in cultured neurons is mediated via $N$-methyl-D-aspartate (NMDA) as well as non-NMDA receptors. J Neurochem 1989; 53: 297-9.

25 Noh KM, Yokota H, Mashiko T, Castillo PE, Zukin RS, Bennett MV. Blockade of calcium-permeable AMPA receptors protects hippocampal neurons against global ischemia-induced death. Proc Natl Acad Sci U S A 2005; 102: 12230-5.

26 Aarts M, Liu Y, Liu L, Besshoh S, Arundine M, Gurd JW, et al. Treatment of ischemic brain damage by perturbing NMDA receptorPSD-95 protein interactions. Science 2002; 298: 846-50.

27 Ginsberg MD. Neuroprotection for ischemic stroke: past, present and future. Neuropharmacology 2008; 55: 363-89.

28 Villmann C, Becker CM. On the hypes and falls in neuroprotection: targeting the NMDA receptor. Neuroscientist 2007; 13: 594-615.

29 Malenka RC, Nicoll RA. Long-term potentiation - a decade of progress? Science 1999; 285: 1870-4.

30 Lisman J, Schulman $\mathrm{H}$, Cline $\mathrm{H}$. The molecular basis of CaMKII function in synaptic and behavioural memory. Nat Rev Neurosci 2002; 3: 175-90.

31 Hudmon A, Schulman H. Neuronal $\mathrm{Ca}^{2+} /$ calmodulin-dependent protein kinase II: the role of structure and autoregulation in cellular function. Annu Rev Biochem 2002; 71: 473-510.

32 Ryazanov AG, Ward MD, Mendola CE, Pavur KS, Dorovkov MV, Wiedmann $\mathrm{M}$, et al. Identification of a new class of protein kinases represented by eukaryotic elongation factor-2 kinase. Proc Natl Acad Sci U S A 1997; 94: 4884-9.

33 Manning G, Whyte DB, Martinez R, Hunter T, Sudarsanam S. The protein kinase complement of the human genome. Science 2002; 298: 1912-34.

34 Haribabu B, Hook SS, Selbert MA, Goldstein EG, Tomhave ED, Edelman AM, et al. Human calcium-calmodulin dependent protein kinase I: cDNA cloning, domain structure and activation by phosphorylation at threonine-177 by calcium-calmodulin dependent protein kinase I kinase. EMBO J 1995; 14: 3679-86.

35 Miller SG, Kennedy MB. Regulation of brain type $/ \mathrm{Ca}{ }^{2+} /$ calmodulindependent protein kinase by autophosphorylation: a $\mathrm{Ca}^{2+}$-triggered molecular switch. Cell 1986; 44: 861-70.

36 Lou LL, Lloyd SJ, Schulman H. Activation of the multifunctional $\mathrm{Ca}^{2+}$ / calmodulin-dependent protein kinase by autophosphorylation: ATP modulates production of an autonomous enzyme. Proc Natl Acad Sci U S A 1986; 83: 9497-501.

37 Schworer CM, Colbran RJ, Soderling TR. Reversible generation of a $\mathrm{Ca}^{2+}$-independent form of $\mathrm{Ca}^{2+}$ (calmodulin)-dependent protein kinase II by an autophosphorylation mechanism. J Biol Chem 1986; 261: 8581-4.

38 Kolodziej SJ, Hudmon A, Waxham MN, Stoops JK. Three-dimensional reconstructions of calcium/calmodulin-dependent (CaM) kinase II and truncated CaM kinase II reveal a unique organization for its structural core and functional domains. J Biol Chem 2000; 275: 14354-9.

39 Chen CH, Wang WJ, Kuo JC, Tsai HC, Lin JR, Chang ZF. Bidirectional signals transduced by DAPK-ERK interaction promote the apoptotic effect of DAPK. EMBO J 2005; 24: 294-304.

40 Bialik S, Kimchi A. The death-associated protein kinases: structure, function, and beyond. Annu Rev Biochem 2006; 75: 189-210.

41 Stull JT, Lin PJ, Krueger JK, Trewhella J, Zhi G. Myosin light chain kinase: functional domains and structural motifs. Acta Physiol Scand 1998; 164: 471-82.

42 Oakhill JS, Scott JW, Kemp BE. Structure and function of AMPactivated protein kinase. Acta Physiol 2009; 196: 3-14.

43 Wayman GA, Lee YS, Tokumitsu H, Silva A, Soderling TR. Calmodulinkinases: modulators of neuronal development and plasticity. Neuron 2008; 59: 914-31.
44 Tobimatsu T, Fujisawa $\mathrm{H}$. Tissue-specific expression of four types of rat calmodulin-dependent protein kinase II mRNAs. J Biol Chem 1989; 264: 17907-12.

45 Bayer KU, Lohler J, Schulman H, Harbers K. Developmental expression of the CaM kinase II isoforms: ubiquitous gamma- and deltaCaM kinase II are the early isoforms and most abundant in the developing nervous system. Brain Res Mol Brain Res 1999; 70 : 147-54.

46 Erondu NE, Kennedy MB. Regional distribution of type $\mathrm{II} \mathrm{Ca}^{2+} /$ calmodulin-dependent protein kinase in rat brain. J Neurosci 1985; 5: 3270-7.

47 Hatakeyama T, Matsumoto M, Brengman J, Yanagihara T. Immunohistochemical investigation of ischemic and postischemic damage after bilateral carotid occlusion in gerbils. Stroke 1988; 19: 152634.

48 Silva AJ, Stevens CF, Tonegawa S, Wang Y. Deficient hippocampal long-term potentiation in alpha-calcium-calmodulin kinase II mutant mice. Science 1992; 257: 201-6.

49 Silva AJ, Paylor R, Wehner JM, Tonegawa S. Impaired spatial learning in alpha-calcium-calmodulin kinase II mutant mice. Science 1992; 257: 206-11.

50 Hoelz A, Nairn AC, Kuriyan J. Crystal structure of a tetradecameric assembly of the association domain of $\mathrm{Ca}^{2+} /$ calmodulin-dependent kinase II. Mol Cell 2003; 11: 1241-51.

51 Rosenberg OS, Deindl S, Sung RJ, Nairn AC, Kuriyan J. Structure of the autoinhibited kinase domain of CaMKII and SAXS analysis of the holoenzyme. Cell 2005; 123: 849-60.

52 Rosenberg OS, Deindl S, Comolli LR, Hoelz A, Downing KH, Nairn $\mathrm{AC}$, et al. Oligomerization states of the association domain and the holoenyzme of Ca/CaM kinase II. FEBS J 2006; 273: 682-94.

53 Rellos P, Pike AC, Niesen FH, Salah E, Lee WH, von Delft F, et al. Structure of the CaMKIldelta/calmodulin complex reveals the molecular mechanism of CaMKII kinase activation. PLoS Biol 2010; 8: e1000426.

54 Bayer KU, Harbers K, Schulman $\mathrm{H}$. alphaKAP is an anchoring protein for a novel CaM kinase II isoform in skeletal muscle. EMBO J 1998; 17: 5598-605.

55 Schulman H, Greengard P. Stimulation of brain membrane protein phosphorylation by calcium and an endogenous heat-stable protein. Nature 1978; 271: 478-9.

56 Bennett MK, Erondu NE, Kennedy MB. Purification and characterization of a calmodulin-dependent protein kinase that is highly concentrated in brain. J Biol Chem 1983; 258: 12735-44.

57 Yamauchi T, Ohsako S, Deguchi T. Expression and characterization of calmodulin-dependent protein kinase II from cloned cDNAs in Chinese hamster ovary cells. J Biol Chem 1989; 264: 19108-16.

58 Kolb SJ, Hudmon A, Ginsberg TR, Waxham MN. Identification of domains essential for the assembly of calcium/calmodulin-dependent protein kinase II holoenzymes. J Biol Chem 1998; 273: 3155564.

59 Brocke L, Chiang LW, Wagner PD, Schulman H. Functional implications of the subunit composition of neuronal CaM kinase II. J Biol Chem 1999; 274: 22713-22.

60 Lantsman K, Tombes RM. CaMK-II oligomerization potential determined using CFP/YFP FRET. Biochim Biophys Acta 2005; 1746: 45-54.

61 Kanaseki T, Ikeuchi Y, Sugiura H, Yamauchi T. Structural features of $\mathrm{Ca}^{2+} /$ calmodulin-dependent protein kinase II revealed by electron microscopy. J Cell Biol 1991; 115: 1049-60.

62 Morris EP, Török K. Oligomeric structure of [alpha]-calmodulindependent protein kinase II. J Mol Biol 2001; 308: 1-8.

63 Yang E, Schulman H. Structural examination of autoregulation of multifunctional calcium/calmodulin-dependent protein kinase II. J 
Biol Chem 1999; 274: 26199-208.

64 Bayer KU, De Koninck P, Leonard AS, Hell JW, Schulman H. Interaction with the NMDA receptor locks CaMKII in an active conformation. Nature 2001; 411: 801-5.

65 Hanson PI, Meyer T, Stryer L, Schulman H. Dual role of calmodulin in autophosphorylation of multifunctional CaM kinase may underlie decoding of calcium signals. Neuron 1994; 12: 943-56.

66 Rich RC, Schulman H. Substrate-directed function of calmodulin in autophosphorylation of $\mathrm{Ca}^{2+} /$ calmodulin-dependent protein kinase II. J Biol Chem 1998; 273: 28424-9.

67 Coultrap SJ, Buard I, Kulbe JR, Dell'Acqua ML, Bayer KU. CaMKII autonomy is substrate-dependent and further stimulated by $\mathrm{Ca}^{2+} /$ calmodulin. J Biol Chem 2010; 285: 17930-7.

68 Giese KP, Fedorov NB, Filipkowski RK, Silva AJ. Autophosphorylation at Thr286 of the alpha calcium-calmodulin kinase II in LTP and learning. Science 1998; 279: 870-3.

69 Colbran RJ, Soderling TR. Calcium/calmodulin-independent autophosphorylation sites of calcium/calmodulin-dependent protein kinase II. Studies on the effect of phosphorylation of threonine $305 / 306$ and serine 314 on calmodulin binding using synthetic peptides. J Biol Chem 1990; 265: 11213-9.

70 Hanson PI, Schulman $\mathrm{H}$. Inhibitory autophosphorylation of multifunctional $\mathrm{Ca}^{2+} /$ calmodulin-dependent protein kinase analyzed by sitedirected mutagenesis. J Biol Chem 1992; 267: 17216-24.

71 Colbran RJ. Inactivation of $\mathrm{Ca}^{2+} /$ calmodulin-dependent protein kinase II by basal autophosphorylation. J Biol Chem 1993; 268: 7163-70.

72 Lu CS, Hodge JJ, Mehren J, Sun XX, Griffith LC. Regulation of the $\mathrm{Ca}^{2+} /$ CaM-responsive pool of CaMKII by scaffold-dependent autophosphorylation. Neuron 2003; 40: 1185-97.

73 Malinow R, Schulman H, Tsien RW. Inhibition of postsynaptic PKC or CaMKII blocks induction but not expression of LTP. Science 1989; 245: 862-6.

74 Buard I, Coultrap SJ, Freund RK, Lee YS, Dell'Acqua ML, Silva AJ, et al. CaMKII "autonomy" is required for initiating but not for maintaining neuronal long-term information storage. J Neurosci 2010; 30: 8214-20.

75 Lee YS, Silva AJ. The molecular and cellular biology of enhanced cognition. Nat Rev Neurosci 2009; 10: 126-40.

76 Shen K, Meyer T. Dynamic control of CaMKII translocation and localization in hippocampal neurons by NMDA receptor stimulation. Science 1999; 284: 162-6.

77 Otmakhov N, Tao-Cheng JH, Carpenter S, Asrican B, Dosemeci A, Reese TS, et al. Persistent accumulation of calcium/calmodulindependent protein kinase II in dendritic spines after induction of NMDA receptor-dependent chemical long-term potentiation. J Neurosci 2004; 24: 9324-31.

78 Bayer KU, LeBel E, McDonald GL, O'Leary H, Schulman H, De Koninck $\mathrm{H}$, et al. Transition from reversible to persistent binding of CaMKII to postsynaptic sites and NR2B. J Neurosci 2006; 26: 1164-74.

79 Hudmon A, Aronowski J, Kolb SJ, Waxham MN. Inactivation and selfassociation of $\mathrm{Ca}^{2+} /$ calmodulin-dependent protein kinase II during autophosphorylation. J Biol Chem 1996; 271: 8800-8.

80 Dosemeci A, Reese TS, Petersen J, Tao-Cheng JH. A novel particulate form of $\mathrm{Ca}^{2+} / \mathrm{CaMKII-dependent} \mathrm{protein} \mathrm{kinase} \mathrm{II} \mathrm{in} \mathrm{neurons.} \mathrm{J}$ Neurosci 2000; 20: 3076-84.

81 Tao-Cheng JH, Vinade L, Smith C, Winters CA, Ward R, Brightman $\mathrm{MW}$, et al. Sustained elevation of calcium induces $\mathrm{Ca}^{2+} /$ calmodulindependent protein kinase II clusters in hippocampal neurons. Neuroscience 2001; 106: 69-78.

82 Hudmon A, Lebel E, Roy H, Sik A, Schulman H, Waxham MN, et al. A mechanism for $\mathrm{Ca}^{2+} /$ calmodulin-dependent protein kinase II clustering at synaptic and nonsynaptic sites based on self-association. J
Neurosci 2005; 25: 6971-83.

83 Barria A, Malinow R. NMDA receptor subunit composition controls synaptic plasticity by regulating binding to CaMKII. Neuron 2005; 48: 289-301.

84 Zhou Y, Takahashi E, Li W, Halt A, Wiltgen B, Ehninger D, et al. Interactions between the NR2B receptor and CaMKII modulate synaptic plasticity and spatial learning. J Neurosci 2007; 27: 13843-53.

85 Strack S, Colbran RJ. Autophosphorylation-dependent targeting of calcium/calmodulin-dependent protein kinase II by the NR2B subunit of the $N$-methyl- $D$-aspartate receptor. J Biol Chem 1998; 273: 20689-92.

86 Leonard AS, Bayer KU, Merrill MA, Lim IA, Shea MA, Schulman H, et al. Regulation of calcium/calmodulin-dependent protein kinase II docking to $N$-methyl- $D$-aspartate receptors by calcium/calmodulin and alpha-actinin. J Biol Chem 2002; 277: 48441-8.

87 Bayer KU, Schulman H. Regulation of signal transduction by protein targeting: the case for CaMKII. Biochem Biophys Res Commun 2001; 289: 917-23.

88 Colbran RJ, Brown AM. Calcium/calmodulin-dependent protein kinase II and synaptic plasticity. Curr Opin Neurobiol 2004; 14 : 318-27.

89 Merrill MA, Chen Y, Strack S, Hell JW. Activity-driven postsynaptic translocation of CaMKII. Trends Pharmacol Sci 2005; 26: 645-53.

90 Hudmon A, Kim SA, Kolb SJ, Stoops JK, Waxham MN. Light scattering and transmission electron microscopy studies reveal a mechanism for calcium/calmodulin-dependent protein kinase II self-association. J Neurochem 2001; 76: 1364-75.

91 Vest RS, O'Leary H, Bayer KU. Differential regulation by ATP versus ADP further links CaMKII aggregation to ischemic conditions. FEBS Lett 2009; 583: 3577-81.

92 Strack S, McNeill RB, Colbran RJ. Mechanism and regulation of calcium/calmodulin-dependent protein kinase II targeting to the NR2B subunit of the $\mathrm{N}$-methyl- $D$-aspartate receptor. J Biol Chem 2000; 275: 23798-806.

93 Aronowski J, Grotta JC, Waxham MN. Ischemia-induced translocation of $\mathrm{Ca}^{2+} /$ calmodulin-dependent protein kinase II: potential role in neuronal damage. J Neurochem 1992; 58: 1743-53.

94 Westgate SA, Brown J, Aronowski J, Waxham MN. Activity of $\mathrm{Ca}^{2+}$ / calmodulin-dependent protein kinase II following ischemia: a comparison between CA1 and dentate gyrus in a hippocampal slice model. J Neurochem 1994; 63: 2217-24.

95 Churn S, Limbrick D, Sombati S, DeLorenzo R. Excitotoxic activation of the NMDA receptor results in inhibition of calcium/calmodulin kinase II activity in cultured hippocampal neurons. J Neurosci 1995; 15: 3200-14.

96 Tokumitsu H, Chijiwa T, Hagiwara M, Mizutani A, Terasawa M, Hidaka H. KN-62,1-[N,O-bis(5-isoquinolinesulfonyl)- $N$-methyl-L-tyrosyl]-4phenylpiperazi ne, a specific inhibitor of $\mathrm{Ca}^{2+} /$ calmodulin-dependent protein kinase II. J Biol Chem 1990; 265: 4315-20.

97 Sumi M, Kiuchi K, Ishikawa T, Ishii A, Hagiwara M, Nagatsu T, et al. The newly synthesized selective $\mathrm{Ca}^{2+} /$ calmodulin dependent protein kinase II inhibitor KN-93 reduces dopamine contents in $\mathrm{PC} 12 \mathrm{~h}$ cells. Biochem Biophys Res Commun 1991; 181: 968-75.

98 Davies SP, Reddy H, Caivano M, Cohen P. Specificity and mechanism of action of some commonly used protein kinase inhibitors. Biochem J 2000; 351: 95-105.

99 Enslen H, Sun P, Brickey D, Soderling SH, Klamo E, Soderling TR. Characterization of $\mathrm{Ca}^{2+}$ /calmodulin-dependent protein kinase IV. Role in transcriptional regulation. J Biol Chem 1994; 269: 15520-7.

100 Dell'Acqua ML, Scott JD. Protein kinase A anchoring. J Biol Chem 1997; 272: 12881-4.

101 Brooks IM, Tavalin SJ. CaMKII inhibitors disrupt AKAP79-dependent PKC signaling to GluA1 AMPA receptors. J Biol Chem 2011; 286: 
6697-706.

$102 \mathrm{Li} \mathrm{G}$, Hidaka H, Wollheim CB. Inhibition of voltage-gated $\mathrm{Ca}^{2+}$ channels and insulin secretion in HIT cells by the $\mathrm{Ca}^{2+} /$ calmodulindependent protein kinase II inhibitor KN-62: comparison with antagonists of calmodulin and L-type $\mathrm{Ca}^{2+}$ channels. Mol Pharmacol 1992; 42: 489-8.

103 Ledoux J, Chartier D, Leblanc N. Inhibitors of calmodulin-dependent protein kinase are nonspecific blockers of voltage-dependent $\mathrm{K}^{+}$ channels in vascular myocytes. J Pharmacol Exp Ther 1999; 290: 1165-74.

104 Ishida A, Kameshita I, Okuno S, Kitani T, Fujisawa H. A novel highly specific and potent inhibitor of calmodulin-dependent protein kinase II. Biochem Biophys Res Commun 1995; 212: 806-12.

105 Patel R, Holt M, Philipova R, Moss S, Schulman H, Hidaka H, et al. Calcium/calmodulin-dependent phosphorylation and activation of human Cdc25-C at the $\mathrm{G}_{2} / \mathrm{M}$ phase transition in HeLa cells. J Biol Chem 1999; 274: 7958-68.

106 Hvalby O, Hemmings HC Jr, Paulsen O, Czernik AJ, Nairn AC, Godfraind JM, et al. Specificity of protein kinase inhibitor peptides and induction of long-term potentiation. Proc Natl Acad Sci U S A 1994; 91: 4761-5.

107 Smith MK, Colbran RJ, Soderling TR. Specificities of autoinhibitory domain peptides for four protein kinases. Implications for intact cell studies of protein kinase function. J Biol Chem 1990; 265: $1837-$ 40.

108 Backs J, Backs T, Neef S, Kreusser MM, Lehmann LH, Patrick DM, et al. The delta isoform of CaM kinase II is required for pathological cardiac hypertrophy and remodeling after pressure overload. Proc Natl Acad Sci U S A 2009; 106: 2342-7.

109 Patel R, Holt M, Philipova R, Moss S, Schulman H, Hidaka H, et al. Calcium/calmodulin-dependent phosphorylation and activation of human $\mathrm{Cdc} 25-\mathrm{C}$ at the $\mathrm{G}_{2} / \mathrm{M}$ phase transition in HeLa cells. J Biol Chem 1999; 274: 7958-68.

110 Chen HX, Otmakhov N, Strack S, Colbran RJ, Lisman JE. Is persistent activity of calcium/calmodulin-dependent kinase required for the maintenance of LTP? J Neurophysiol 2001; 85: 1368-76.

111 Vest RS, Davies KD, O'Leary H, Port JD, Bayer KU. Dual mechanism of a natural CaMKII inhibitor. Mol Biol Cell 2007; 18: 5024-33.

112 Chang BH, Mukherji S, Soderling TR. Characterization of a calmodulin kinase II inhibitor protein in brain. Proc Natl Acad Sci U S A 1998; 95: 10890-5.

113 Schwartz JJ, Zhang S. Peptide-mediated cellular delivery. Curr Opin Mol Ther 2000; 2: 162-7.

114 Green I, Christison R, Voyce CJ, Bundell KR, Lindsay MA. Protein transduction domains: are they delivering? Trends Pharmacol Sci 2003; 24: 213-5.

115 Joliot A, Prochiantz A. Transduction peptides: from technology to physiology. Nat Cell Biol 2004; 6: 189-96.

116 Fink CC, Bayer KU, Myers JW, Ferrell JE Jr, Schulman H, Meyer T. Selective regulation of neurite extension and synapse formation by the beta but not the alpha isoform of CaMKII. Neuron 2003; 39: 283-97.

117 Illario M, Cavallo AL, Bayer KU, Di Matola T, Fenzi G, Rossi G, et al. Calcium/calmodulin-dependent protein kinase II binds to Raf-1 and modulates integrin-stimulated ERK activation. J Biol Chem 2003; 278: 45101-8.

118 Schwarze SR, Ho A, Vocero-Akbani A, Dowdy SF. In vivo protein transduction: delivery of a biologically active protein into the mouse. Science 1999; 285: 1569-72.

119 Hajimohammadreza I, Probert AW, Coughenour LL, Borosky SA, Marcoux FW, Boxer PA, et al. A specific inhibitor of calcium/ calmodulin-dependent protein kinase-II provides neuroprotection against NMDA- and hypoxia/hypoglycemia-induced cell death. J
Neurosci 1995; 15: 4093-101.

120 Laabich A, Cooper NG. Neuroprotective effect of AIP on N-methyl-Daspartate-induced cell death in retinal neurons. Brain Res Mol Brain Res 2000; 85: 32-40.

121 Takano H, Fukushi H, Morishima Y, Shirasaki Y. Calmodulin and calmodulin-dependent kinase II mediate neuronal cell death induced by depolarization. Brain Res 2003; 962: 41-7.

122 Fan W, Agarwal N, Cooper NG. The role of CaMKII in BDNF-mediated neuroprotection of retinal ganglion cells (RGC-5). Brain Res 2006; 1067: 48-57.

123 Gao J, Duan B, Wang DG, Deng XH, Zhang GY, Xu L, et al. Coupling between NMDA receptor and acid-sensing ion channel contributes to ischemic neuronal death. Neuron 2005; 48: 635-46.

124 Waxham MN, Grotta JC, Silva AJ, Strong R, Aronowski J. Ischemiainduced neuronal damage: a role for calcium/calmodulin-dependent protein kinase II. J Cereb Blood Flow Metab 1996; 16: 1-6.

125 Mabuchi T, Kitagawa K, Kuwabara K, Takasawa K, Ohtsuki T, Xia Z, et al. Phosphorylation of CAMP response element-binding protein in hippocampal neurons as a protective response after exposure to glutamate in vitro and ischemia in vivo. J Neurosci 2001; 21: 920413.

126 Linseman DA, Bartley CM, Le SS, Laessig TA, Bouchard RJ, Meintzer $\mathrm{MK}$, et al. Inactivation of the myocyte enhancer factor-2 repressor histone deacetylase- 5 by endogenous $\mathrm{Ca}^{2+}$ /calmodulin-dependent kinase II promotes depolarization-mediated cerebellar granule neuron survival. J Biol Chem 2003; 278: 41472-81.

127 Bok J, Wang Q, Huang J, Green SH. CaMKII and CaMKIV mediate distinct prosurvival signaling pathways in response to depolarization in neurons. Mol Cell Neurosci 2007; 36: 13-26.

128 Hansen MR, Bok J, Devaiah AK, Zha XM, Green SH. Ca ${ }^{2+} /$ calmodulindependent protein kinases II and IV both promote survival but differ in their effects on axon growth in spiral ganglion neurons. J Neurosci Res 2003; 72: 169-84.

129 Butler LS, Silva AJ, Abeliovich A, Watanabe Y, Tonegawa S, McNamara JO. Limbic epilepsy in transgenic mice carrying a $\mathrm{Ca}^{2+} /$ calmodulindependent kinase II alpha-subunit mutation. Proc Natl Acad Sci U S A 1995; 92: 6852-5.

130 Yamagata Y, Kobayashi S, Umeda T, Inoue A, Sakagami H, Fukaya $\mathrm{M}$, et al. Kinase-dead knock-in mouse reveals an essential role of kinase activity of $\mathrm{Ca}^{2+} /$ calmodulin-dependent protein kinase II\{alpha\} in dendritic spine enlargement, long-term potentiation, and learning. J Neurosci 2009; 29: 7607-18.

131 Finkbeiner S, Tavazoie SF, Maloratsky A, Jacobs KM, Harris KM, Greenberg ME. CREB: a major mediator of neuronal neurotrophin responses. Neuron 1997; 19: 1031-47.

132 See V, Boutillier AL, Bito H, Loeffler JP. Calcium/calmodulindependent protein kinase type IV (CaMKIV) inhibits apoptosis induced by potassium deprivation in cerebellar granule neurons. FASEB J 2001; 15: 134-44.

133 Wu GY, Deisseroth K, Tsien RW. Activity-dependent CREB phosphorylation: convergence of a fast, sensitive calmodulin kinase pathway and a slow, less sensitive mitogen-activated protein kinase pathway. Proc Natl Acad Sci U S A 2001; 98: 2808-13.

134 Wayman GA, Impey S, Marks D, Saneyoshi T, Grant WF, Derkach V, et al. Activity-dependent dendritic arborization mediated by CaM-kinase I activation and enhanced CREB-dependent transcription of Wnt-2. Neuron 2006; 50: 897-909.

135 Tokumitsu H, Inuzuka H, Ishikawa Y, Ikeda M, Saji I, Kobayashi R. STO-609, a specific inhibitor of the $\mathrm{Ca}^{2+} /$ calmodulin-dependent protein kinase kinase. J Biol Chem 2002; 277: 15813-8.

136 Yano S, Tokumitsu H, Soderling TR. Calcium promotes cell survival through CaM-K kinase activation of the protein-kinase-B pathway. Nature 1998; 396: 584-7. 
137 Hurley RL, Anderson KA, Franzone JM, Kemp BE, Means AR, Witters $\mathrm{LA}$. The $\mathrm{Ca}^{2+} /$ calmodulin-dependent protein kinase kinases are AMPactivated protein kinase kinases. J Biol Chem 2005; 280: 29060-6.

$138 \mathrm{Li} \mathrm{J,} \mathrm{McCullough} \mathrm{LD.} \mathrm{Effects} \mathrm{of} \mathrm{AMP-activated} \mathrm{protein} \mathrm{kinase} \mathrm{in}$ cerebral ischemia. J Cereb Blood Flow Metab 2010; 30: 480-92.

139 Li J, Benashski SE, Venna VR, McCullough LD. Effects of metformin in experimental stroke. Stroke 2010; 41: 2645-52.

140 Schurr A, Reid KH, Tseng MT, West C, Rigor BM. Adaptation of adult brain tissue to anoxia and hypoxia in vitro. Brain Res 1986; 374 : 244-8.

141 Kitagawa K, Matsumoto M, Tagaya M, Hata R, Ueda H, Niinobe M, et al. Ischemic tolerance' phenomenon found in the brain. Brain Res 1990; 528: 21-4.

142 Liu Y, Kato H, Nakata N, Kogure K. Protection of rat hippocampus against ischemic neuronal damage by pretreatment with sublethal ischemia. Brain Research 1992; 586: 121-4.

143 Kirino T. Ischemic tolerance. J Cereb Blood Flow Metab 2002; 22: 1283-96.

144 McCullough LD, Zeng Z, Li H, Landree LE, McFadden J, Ronnett GV. Pharmacological inhibition of AMP-activated protein kinase provides neuroprotection in stroke. J Biol Chem 2005; 280: 20493-502.

145 Tu W, Xu X, Peng L, Zhong X, Zhang W, Soundarapandian MM, et al. DAPK1 interaction with NMDA receptor NR2B subunits mediates brain damage in stroke. Cell 2010; 140: 222-34.

146 Zhou L, Li F, Xu HB, Luo CX, Wu HY, Zhu MM, et al. Treatment of cerebral ischemia by disrupting ischemia-induced interaction of nNOS with PSD-95. Nat Med 2010; 16: 1439-43.

147 Derkach V, Barria A, Soderling TR. $\mathrm{Ca}^{2+} /$ calmodulin-kinase II enhances channel conductance of alpha-amino-3-hydroxy-5-methyl4-isoxazolepropionate type glutamate receptors. Proc Natl Acad Sci U S A 1999; 96: 3269-74.

148 Barria A, Muller D, Derkach V, Griffith LC, Soderling TR. Regulatory phosphorylation of AMPA-type glutamate receptors by CaM-KII during long-term potentiation. Science 1997; 276: 2042-5.

149 Oh MC, Derkach VA. Dominant role of the GluR2 subunit in regulation of AMPA receptors by CaMKII. Nat Neurosci 2005; 8: 853-4.

150 Hollmann M, Hartley M, Heinemann S. $\mathrm{Ca}^{2+}$ permeability of KAAMPA-gated glutamate receptor channels depends on subunit composition. Science 1991; 252: 851-3.

151 Verdoorn T, Burnashev N, Monyer H, Seeburg P, Sakmann, B. Structural determinants of ion flow through recombinant glutamate receptor channels. Science 1991; 252: 1715-8.

152 Liu SJ, Zukin RS. $\mathrm{Ca}^{2+}$-permeable AMPA receptors in synaptic plasticity and neuronal death. Trends Neurosci 2007; 30: 126-34.

153 Hudmon A, Schulman H, Kim J, Maltez JM, Tsien RW, Pitt GS. CaMKII tethers to L-type $\mathrm{Ca}^{2+}$ channels, establishing a local and dedicated integrator of $\mathrm{Ca}^{2+}$ signals for facilitation. J Cell Biol 2005; 171: $537-$ 47.

154 Grueter CE, Abiria SA, Dzhura I, Wu Y, Ham AJ, Mohler PJ, et al. L-type $\mathrm{Ca}^{2+}$ channel facilitation mediated by phosphorylation of the beta subunit by CaMKII. Mol Cell 2006; 23: 641-50.

155 Alev C, Urschel S, Sonntag S, Zoidl G, Fort AG, Hoher T, et al. The neuronal connexin36 interacts with and is phosphorylated by CaMKII in a way similar to CaMKII interaction with glutamate receptors. Proc Natl Acad Sci U S A 2008; 105: 20964-9.

156 Oguro K, Jover T, Tanaka H, Lin Y, Kojima T, Oguro N, et al. Global ischemia-induced increases in the gap junctional proteins connexin 32 (Cx32) and Cx36 in hippocampus and enhanced vulnerability of Cx32 knock-out mice. J Neurosci 2001; 21: 7534-42.

157 Bargiotas P, Monyer H, Schwaninger, M. Hemichannels in cerebral ischemia. Curr Mol Med 2009; 9: 186-94.

158 Contreras JE, Sanchez HA, Veliz LP, Bukauskas FF, Bennett MV, Saez JC. Role of connexin-based gap junction channels and hemichannels in ischemia-induced cell death in nervous tissue. Brain Res Brain Res Rev 2004; 47: 290-303.

159 Kan MC, Oruganty-Das A, Cooper-Morgan A, Jin G, Swanger SA, Bassell GJ, et al. CPEB4 is a cell survival protein retained in the nucleus upon ischemia or endoplasmic reticulum calcium depletion. Mol Cell Biol 2010; 30: 5658-71.

160 Wells DG. RNA-binding proteins: a lesson in repression. J Neurosci 2006; 26: 7135-8.

161 Richter JD. CPEB: a life in translation. Trends Biochem Sci 2007; 32: 279-85.

162 Wu L, Wells D, Tay J, Mendis D, Abbott MA, Barnitt A, et al. CPEBmediated cytoplasmic polyadenylation and the regulation of experience-dependent translation of [alpha]-camkii mrna at synapses. Neuron 1998; 21: 1129-39.

163 Kundel M, Jones KJ, Shin CY, Wells DG. Cytoplasmic polyadenylation element-binding protein regulates neurotrophin-3-dependent \{beta\}catenin mrna translation in developing hippocampal neurons. J Neurosci 2009; 29: 13630-9.

164 Li X, Klaus JA, Zhang J, Xu Z, Kibler KK, Andrabi SA, et al. Contributions of poly(ADP-ribose) polymerase-1 and -2 to nuclear translocation of apoptosis-inducing factor and injury from focal cerebral ischemia. J Neurochem 2010; 113: 1012-22.

165 Komeima K, Hayashi Y, Naito Y, Watanabe Y. Inhibition of neuronal nitric-oxide synthase by calcium/calmodulin-dependent protein kinase II through Ser847 phosphorylation in NG108-15 neuronal cells. J Biol Chem 2000; 275: 28139-43.

166 Osuka K, Watanabe Y, Usuda N, Nakazawa A, Fukunaga K, Miyamoto $\mathrm{E}$, et al. Phosphorylation of neuronal nitric oxide synthase at Ser847 by CaM-KII in the hippocampus of rat brain after transient forebrain ischemia. J Cereb Blood Flow Metab 2002; 22: 1098-106.

167 Rameau GA, Chiu LY, Ziff EB. Bidirectional regulation of neuronal nitric-oxide synthase phosphorylation at Serine 847 by the $N$-methylD-aspartate receptor . J Biol Chem 2004; 279: 14307-14.

168 Rameau GA, Tukey DS, Garcin-Hosfield ED, Titcombe RF, Misra C, Khatri $\mathrm{L}$, et al. Biphasic coupling of neuronal nitric oxide synthase phosphorylation to the NMDA receptor regulates AMPA receptor trafficking and neuronal cell death. J Neurosci 2007; 27: 3445-55.

169 Dawson V, Kizushi V, Huang P, Snyder S, Dawson T. Resistance to neurotoxicity in cortical cultures from neuronal nitric oxide synthasedeficient mice. J Neurosci 1996; 16: 2479-87.

170 Eliasson MJL, Huang Z, Ferrante RJ, Sasamata M, Molliver ME, Snyder SH, et al. Neuronal nitric oxide synthase activation and peroxynitrite formation in ischemic stroke linked to neural damage. J Neurosci 1999; 19: 5910-8.

171 Oka M, Hirouchi M, Itoh Y, Ukai Y. Involvement of peroxynitrite and hydroxyradical generated from nitric oxide in hypoxia/reoxygenation injury in rat cerebrocortical slices. Neuropharmacology 2000; 39: 1319-30.

172 Zhou L, Zhu DY. Neuronal nitric oxide synthase: structure, subcellular localization, regulation, and clinical implications. Nitric Oxide 2009; 20: $223-30$.

173 Sessoms-Sikes S, Honse Y, Lovinger DM, Colbran RJ. CaMKIlalpha enhances the desensitization of NR2B-containing NMDA receptors by an autophosphorylation-dependent mechanism. Mol Cell Neurosci 2005; 29: 139-47.

174 Marsden KC, Beattie JB, Friedenthal J, Carroll RC. NMDA receptor activation potentiates inhibitory transmission through GABA receptorassociated protein-dependent exocytosis of GABAA receptors. J Neurosci 2007; 27: 14326-37.

175 Marsden KC, Shemesh A, Bayer KU, Carroll RC. Selective translocation of $\mathrm{Ca}^{2+} /$ calmodulin protein kinase Ilalpha (CaMKIlalpha) to inhibitory synapses. Proc Natl Acad Sci U S A 2010; 107: 20559-64.

176 Nguyen A, Chen P, Cai H. Role of CaMKII in hydrogen peroxide 
activation of ERK1/2, p38 MAPK, HSP27 and actin reorganization in endothelial cells. FEBS Lett 2004; 572: 307-13.

177 Wheeler DG, Barrett CF, Groth RD, Safa P, Tsien RW. CaMKII locally encodes L-type channel activity to signal to nuclear CREB in excitation-transcription coupling. J Cell Biol 2008; 183: 849-63.

178 Song B, Lai B, Zheng Z, Zhang Y, Luo J, Wang C, et al. Inhibitory phosphorylation of GSK-3 by CaMKII couples depolarization to neuronal survival. J Biol Chem 2010; 285: 41122-34.

179 Mao Z, Bonni A, Xia F, Nadal-Vicens M, Greenberg ME. Neuronal activity-dependent cell survival mediated by transcription factor MEF2. Science 1999; 286: 785-90.

180 Rudin CM, Thompson CB. Apoptosis and disease: regulation and clinical relevance of programmed cell death. Annu Rev Med 1997; 48: $267-81$.

181 Strasser A, O'Connor L, Dixit VM. Apoptosis signaling. Annu Rev Biochem 2000; 69: 217-45.

182 Hengartner MO. The biochemistry of apoptosis. Nature 2000; 407: 770-6.

183 Heidenreich KA. Molecular mechanisms of neuronal cell death. Ann NY Acad Sci 2003; 991: 237-250.

184 Wright S, Schellenberger U, Ji L, Wang H, Larrick J. Calmodulindependent protein kinase II mediates signal transduction in apoptosis. FASEB J 1997; 11: 843-9.

185 Fladmark KE, Brustugun OT, Mellgren G, Krakstad C, Boe R, Vintermyr $\mathrm{OK}$, et al. $\mathrm{Ca}^{2+} /$ calmodulin-dependent protein kinase ii is required for microcystin-induced apoptosis. J Biol Chem 2002; 277: 2804-11.

186 Krakstad C, Herfindal L, Gjertsen BT, Boe R, Vintermyr OK, Fladmark $\mathrm{KE}$, et al. CaM-kinasell-dependent commitment to microcystininduced apoptosis is coupled to cell budding, but not to shrinkage or chromatin hypercondensation. Cell Death Differ 2005; 13: 1191202.

187 Bissonnette SL, Haas A, Mann KK, Schlezinger JJ. The role of CaMKII in calcium-activated death pathways in bone marrow B cells. Toxicol Sci 2010; 118: 108-18.

188 Timmins JM, Ozcan L, Seimon TA, Li G, Malagelada C, Backs J, et al. Calcium/calmodulin-dependent protein kinase II links ER stress with Fas and mitochondrial apoptosis pathways. J Clin Invest 2009; 119: 2925-41.

189 Fujikawa K, Kawakami A, Tanaka F, Iwamoto N, Tamai M, Eguchi K. Calcium/calmodulin-dependent protein kinase II (CaMKII) regulates tumour necrosis factor-related apoptosis inducing ligand (TRAIL)-mediated apoptosis of fibroblast-like synovial cells (FLS) by phosphorylation of Akt. Clin Exp Rheumatol 2009; 27: 952-7.

190 Zhu WZ, Wang SQ, Chakir K, Yang D, Zhang T, Brown JH, et al. Linkage of beta1-adrenergic stimulation to apoptotic heart cell death through protein kinase A-independent activation of $\mathrm{Ca}^{2+} /$ calmodulin kinase II. J Clin Invest 2003; 111: 617-25.

191 Yang Y, Zhu WZ, Joiner MI, Zhang R, Oddis CV, Hou Y, et al. Calmodulin kinase II inhibition protects against myocardial cell apoptosis in vivo. Am J Physiol-Heart Circ Physiol 2006; 291: H3065-75.

192 Sapia L, Palomeque J, Mattiazzi A, Petroff MV. $\mathrm{Na}^{+} / \mathrm{K}^{+}$-ATPase inhibition by ouabain induces CaMKII-dependent apoptosis in adult rat cardiac myocytes. J Mol Cell Cardiol 2010; 49: 459-68.

193 Palomeque J, Rueda OV, Sapia L, Valverde CA, Salas M, Petroff $\mathrm{MV}$, et al. Angiotensin II-induced oxidative stress resets the $\mathrm{ca}^{2+}$ dependence of $\mathrm{Ca}^{2+}$-calmodulin protein kinase ii and promotes a death pathway conserved across different species. Circ Res 2009; 105: 1204-12.

194 Peng W, Zhang Y, Zheng M, Cheng H, Zhu W, Cao CM, et al. Cardioprotection by CaMKII-\{delta\}B is mediated by phosphorylation of heat shock factor 1 and subsequent expression of inducible heat shock protein 70. Circ Res 2010; 106: 102-10.

195 Erickson JR, Joiner ML, Guan X, Kutschke W, Yang J, Oddis CV, et al. A dynamic pathway for calcium-independent activation of CaMKII by methionine oxidation. Cell 2008; 133: 462-74.

196 Vila-Petroff M, Salas MA, Said M, Valverde CA, Sapia L, Portiansky $\mathrm{E}$, et al. CaMKII inhibition protects against necrosis and apoptosis in irreversible ischemia-reperfusion injury. Cardiovas Res 2007; 73: 689-98.

197 Salas MA, Valverde CA, Sánchez G, Said M, Rodriguez JS, Portiansky $\mathrm{EL}$, et al. The signalling pathway of CaMKII-mediated apoptosis and necrosis in the ischemia/reperfusion injury. J Mol Cell Cardiol 2010; 48: 1298-306.

198 Mishra S, Ling H, Grimm M, Zhang T, Bers DM, Brown JH. Cardiac hypertrophy and heart failure development through Gq and Cam kinase II signaling. J Cardiovasc Pharmacol 2010; 56: 598-603.

199 Nutt LK, Margolis SS, Jensen M, Herman CE, Dunphy WG, Rathmell $\mathrm{JC}$, et al. Metabolic regulation of oocyte cell death through the CaMKII-mediated phosphorylation of caspase-2. Cell 2005; 123: 89-103.

200 Rokhlin OW, Taghiyev AF, Bayer KU, Bumcrot D, Koteliansk VE, Glover RA, et al. Calcium/calmodulin-dependent kinase II plays an important role in prostate cancer cell survival. Cancer Biol Ther 2007; 6: 732-42.

201 Ma S, Yang Y, Wang C, Hui N, Gu L, Zhong H, et al. Endogenous human CaMKII inhibitory protein suppresses tumor growth by inducing cell cycle arrest and apoptosis through down-regulation of the phosphatidylinositide 3-kinase/Akt/HDM2 pathway. J Biol Chem 2009; 284: 24773-82.

202 Yang CS, Thomenius MJ, Gan EC, Tang W, Freel CD, Merritt TJS, et al. Metabolic regulation of Drosophila apoptosis through inhibitory phosphorylation of Dronc. EMBO J 2010; 29: 3196-207.

203 Kajihara R, Fukushige S, Shioda N, Tanabe K, Fukunaga K, Inui S. CaMKII phosphorylates serine 10 of p27 and confers apoptosis resistance to HeLa cells. Biochem Biophys Res Commun 2010; 401: 350-5.

204 Tano JY, Vazquez G. Requirement for non-regulated, constitutive calcium influx in macrophage survival signaling. Biochem Biophys Res Commun 2011; 407: 432-7.

205 Anderson ME, Brown JH, Bers DM. CaMKII in myocardial hypertrophy and heart failure. J Mol Cell Cardiol 2011. doi: 10.1016/ j.yjmcc.2011.01.012.

206 Srinivasan M, Edman CF, Schulman H. Alternative splicing introduces a nuclear localization signal that targets multifunctional CaM kinase to the nucleus. J Cell Biol 1994; 126: 839-52.

207 Little GH, Saw A, Bai Y, Dow J, Marjoram P, Simkhovich B, et al. Critical role of nuclear calcium/calmodulin-dependent protein kinase iideltab in cardiomyocyte survival in cardiomyopathy. J Biol Chem 2009; 284: 24857-68.

208 Ghosh A, Greenberg M. Calcium signaling in neurons: molecular mechanisms and cellular consequences. Science 1995; 268: 23947.

209 Arundine M, Tymianski M. Molecular mechanisms of calciumdependent neurodegeneration in excitotoxicity. Cell Calcium 2003; 34: 325-37.

210 Hardingham GE, Fukunaga $Y$, Bading $H$. Extrasynaptic NMDARs oppose synaptic NMDARs by triggering CREB shut-off and cell death pathways. Nat Neurosci 2002; 5: 405-14.

211 Zhang SJ, Buchthal B, Lau D, Hayer S, Dick O, Schwaninger M, et al. A Signaling cascade of nuclear calcium-CREB-ATF3 activated by synaptic NMDA receptors defines a gene repression module that protects against extrasynaptic NMDA receptor-induced neuronal cell death and ischemic brain damage. J Neurosci 2011; 31: 4978-90. 